\section{Periodontal disease treatment and risk of preterm birth: a systematic review and meta-analysis}

\author{
Tratamento de doença periodontal e risco de \\ parto prematuro: revisão sistemática e metanálise
}

\author{
${ }_{1}$ Laboratório de \\ Epidemiologia, Universidade \\ do Extremo Sul Catarinense, \\ Criciúma, Brasil. \\ 2 Programa de Pós-graduação \\ em Ciências da Saúde. \\ Universidade do Extremo \\ Sul Catarinense, Criciúma, \\ Brasil. \\ 3 Programa de Pós-graduação \\ em Medicina: Ciências \\ Médicas, Universidade \\ Federal do Rio Grande do Sul, \\ Porto Alegre, Brasil. \\ 4 Programa de Pós-graduação \\ em Epidemiologia, \\ Universidade Federal de \\ Pelotas, Pelotas, Brasil. \\ Correspondence \\ M. I. Rosa \\ Laboratório de \\ Epidemiologia, Universidade \\ do Extremo Sul Catarinense. \\ Av. Universitária 1105, C.P. \\ 3167, Criciúma, SC \\ 88806-000, Brasil. \\ mir@unesc.net
}

\section{Abstract}

The events leading to preterm birth are still not completely understood. A quantitative systematic review was performed to estimate the effects of periodontal care during pregnancy on preventing preterm birth and low birth weight. The meta-analysis included randomized trials with pregnant women with a diagnosis of periodontal disease before 20 weeks of gestation. Relative risk (RR) with 95\% confidence intervals (95\%CI) was calculated. We evaluated the reduction in preterm and low birth weight. Thirteen trials were included, comparing 3,576 women in intervention groups with 3,412 women receiving usual care. The meta-analysis of the effects of periodontal disease treatment during pregnancy indicated a non-significant reduction in preterm births $(R R=0.90 ; 95 \% C I: 0.68-1.19)$ and low birth weights ( $R R=0.92$; 95\%CI: $0.71-1.20)$. The creation and examination of a funnel plot revealed clear evidence of publication bias. In summary, primary periodontal care during pregnancy cannot be considered an efficient way of reducing the incidence of preterm birth.

Periodontal Disease; Premature Birth; Low Birth Weight Infant; Review; Meta-Analysis
Maria Inês da Rosa 1,2

Patrícia Duarte Simões Pires 1

Lidia Rosi Medeiros 3

Maria Isabel Edelweiss 3

Jeovany Martínez-Mesa 4

\section{Introduction}

Preterm labor complicates 10 to $15 \%$ of all pregnancies, is the leading cause of neonatal morbidity and mortality and causes $75 \%$ of neonatal deaths that are not due to congenital anomalies 1 . Preterm birth, defined as childbirth occurring at less than 37 completed weeks (or 259 days) of gestation, is a major determinant of neonatal morbidity and mortality and has long-term, adverse health consequences 2,3. Estimates indicate that, in the United States alone, costs associated with preterm birth, in terms of medical, educational expenditure and lost productivity, were more than US\$26.2 billion in 2005 2. Although the etiology is thought to be multifactorial, the events leading to preterm birth are still not completely understood. It is unclear whether preterm birth results from the interaction of several pathways or from the independent effects of each pathway 2 .

There is convincing evidence that infections in pregnant women may alter normal cytokine and hormone-regulated gestation, which could result in preterm labor, premature rupture of membranes and preterm birth 4 . Periodontitis has been associated with pregnancy outcomes such as preterm birth, low birth weight deliveries and premature rupture of membranes 4 . The development of periodontitis involves the invasion of primarily Gram-negative bacteria through the periodontium, stimulating a chronic inflamma- 
tory response and forming pockets that become infected 5,6. However, according to Oliveira et al. ? non-surgical periodontal treatment during the second semester of gestation did not reduce the risk of preterm birth, low birth weight, or preterm low birth weight.

The link between maternal periodontal disease and preterm birth or low birth weight is a grey area and it remains unclear whether adverse pregnancy outcomes have a causal relationship with periodontal disease or if they are a surrogate for another maternal factor.

The objective of the current work was to conduct a systematic review and meta-analysis of randomized, controlled trials to quantify the relationship between periodontal disease, preterm birth and low birth weight in order to explore the reasons for the ongoing controversies surrounding this issue.

\section{Methods}

The PRISMA guidelines were followed for the meta-analysis of randomized trials 8 .

\section{Inclusion and exclusion criteria}

To be eligible for inclusion in our systematic review, studies had to examine specific treatments for periodontal disease during pregnancy, compare the results of usual care ("intensified") and specific treatment ("less intensified") and report on at least one outcome of interest (preterm birth, low birth weight, and/or preterm low birth weight). We included only randomized trials whose participants met the following criteria: women over the age of 18 with a single gestation at 22 weeks or less, who had gingival inflammation with $\geq 25 \%$ of sites bleeding upon probing and sites with clinical attachment loss $>2 \mathrm{~mm}$. The exclusion criteria included the following: having fewer than 18 natural teeth, indication of prophylactic antibiotics for invasive procedures, occurrence of diabetes prior to pregnancy, and the intention of giving birth at a hospital outside this study.

\section{Search strategy}

We performed a literature search of studies published between 1980 and March 2012 using MEDLINE, Embase, BIOSIS, LILACS, Scopus, the Cochrane Central Register of Controlled Trials, the ISI Web of Science and IBECS. First, we derived three themes that were combined with the Boolean operator "AND". Each theme was created with the Boolean operator "OR" to search for terms appearing as either exploded medical headings (MeSH) or text words. The first theme was "randomized control trial". The second theme was "preterm birth", "low birth weight”, "preterm delivery”, "neonatal deaths", "intrauterine infection", "chorioamnionitis", "perinatal care", "LBW", and "PTB”, and the third theme was "gingivitis", "periodontal treatment", "periodontitis" and "periodontal status". We then manually scanned the reference lists of all identified articles. No restrictions were placed on the language of the publications. All randomized controlled trials that allocated pregnant women to receive treatment with scaling and root planning, versus no treatment or prophylaxis, were eligible for inclusion. Trials were considered eligible if they included patients with documented periodontal disease (periodontitis or gingivitis), as defined by the International Workshop for Classification of Periodontal Diseases and Conditions in 1999. All trials were eligible regardless of the depth and the severity of the periodontal disease. We based our classification of severity of periodontal disease on the conclusions of the 2003 working group of the Centers for Disease Control and Prevention and the American Academy of Periodontology. Based on these classifications, we defined moderate and severe periodontitis in terms of probing depth and clinical attachment loss to enhance the case definitions and provide distinct categories. We excluded randomized trials that included patients with threatened preterm delivery who received tocolytic agents, non-randomized trials and pseudorandomized trials.

\section{Data extraction}

Multiple teams consisting of four reviewers (M.I.R, L.R.M, M.I.E. and P.D.S.P) independently screened the title, abstract and key words of each reference identified by the search and applied the inclusion and exclusion criteria. The same procedure was applied to full text articles and potentially eligible references. Differences in reviewers' opinions were resolved by discussion or a by a fifth reviewer. Data on quality, patient characteristics, interventions and relevant outcomes were independently abstracted by two reviewers (J.M.-M. and M.L.S).

Risk of bias was assessed by considering the adequacy of randomization and allocation concealment, and the comparability of the women in the different study groups. Although periodontal disease is treated with complex interventions, outcome assessors could be blinded to the treatment status of participants, thus minimizing bias. 


\section{Outcomes of interest}

The effects of interventions were compared with respect to the following outcomes: preterm birth ( $<37$ weeks), low birth weight $(<2,500 \mathrm{~g})$.

\section{Statistical analysis}

We measured the inter-rater agreement for study inclusion and methodological quality assessment (weighted $\kappa$ ) ${ }^{9}$ and outcomes were reported using relative risk (RR) with $95 \%$ confidence intervals (95\%CI). Pooled-effect estimates were derived using a random effects model with Mantel-Haenszel statistics 10 . Study heterogeneity was determined using the $\mathrm{I}^{2}$ statistic, in which numbers greater than $75 \%$ suggest considerable heterogeneity ${ }^{9}$, and p-values from the $\chi^{2}$ test. In cases of considerable heterogeneity, no pooled-effect estimate was provided. A sensitivity analysis was planned a priori to compare study results and designs, and to report on study quality, focusing on those defined as "good quality" studies 11.

Meta-analysis was performed using version 5.0.17 of the Review Manager software (Nordic Cochrane Center, Copenhagen, Denmark).

\section{Results}

\section{Identification of eligible trials}

The literature search yielded 62 potentially relevant publications, of which 13 were considered eligible for inclusion in this review (Figure 1) 3,5,6,7, $12,13,14,15,16,17,18,19,20$. Reviews of the reference lists

\section{Figure 1}

Flow chart summarizing the literature search process.

Citations identified by PubMed/Embase search strategy $(n=67)$ :

26 studies were excluded (title and abstracts)

by 4 reviewers

Relevant papers identified in PubMed/Embase $(n=41)$ :

28 studies excluded

11 reviews

9 news, letters, editorials, replays

4 nonrandomized

4 different outcomes

13 primary studies included in meta-analysis 
yielded two further citations. The inter-rater reliability for study selection was good $(\kappa=0.9)$.

\section{Characteristics of trials, participants and interventions}

The 13 trials were conducted in seven countries from five different continents and included 6,988 patients $(3,576$ in the periodontal work group and 3,412 in the control group).

We excluded four randomized trials for the following reasons: one included patients hospitalized for threatened preterm birth that received tocolytic agents 21 , another 22 was a duplicate of Michalowicz et al. ${ }^{6}$, and in another 23 patients were randomized based on the efficacy of periodontal treatment that differed from other included studies.

All reviewed studies were published in English. Table 1 shows the details of the study populations, interventions, outcome assessments and data reporting. Table 2 presents the risk of bias for each trial. Inter-rater agreement of assessments of methodological quality ranged from 0.58 to 1.00 for the eight categories, with an overall agreement of 0.75 . The lowest agreement was in the category other bias, whereas perfect agreement was achieved in the areas of adequate sequence generation and allocation concealment. Although all studies described randomization, nine did not adequately describe the random sequence generation methods 3,5,7,12,15,16,17,18,19,20 and nine did not adequately describe allocation concealment 3,5,7,12,15,16,17,18,19,20. Twelve studies did not use blinding methods for adjudication outcomes 3,5,6,7,12,13,14,15,16,17,18,19,20. Four trials described a modified intention-to-treat analysis $3,6,13,15$. Only two papers 3,6 distinguished between gingivitis and periodontitis (such as periodontal disease) and the remaining authors defined only periodontitis. Unfortunately, there is no universally accepted standard of periodontal disease ${ }^{3}$. Unlike gingivitis, periodontitis cannotbeassessed by visual examination alone. The disease is diagnosed with the use of a probe that is inserted into the gingival crevice between the teeth and gums 6 . Therefore, the other authors establish the depth of each pocket (the insertion loss of the structure of the periodontium, i.e., the cementum, ligament and alveolar bone) according to their own criteria.

Table 1

Characteristics of included studies: treatment for periodontal disease versus usual care.

\begin{tabular}{|c|c|c|c|c|c|c|c|c|}
\hline Reference & $\begin{array}{l}\text { Year of } \\
\text { publica- } \\
\text { tion }\end{array}$ & Country & Design & Patients & $\begin{array}{l}\text { Patient age in years } \\
\text { [mean (SD)] }\end{array}$ & $\begin{array}{l}\text { Diagnosis (periodontal } \\
\text { disease was defined as) }\end{array}$ & Participants & Outcomes \\
\hline López et al. 12 & 2002 & Chile & Randomized & 400 & $\begin{array}{l}\text { Treatment: } 28 \\
\qquad( \pm 4.5) \\
\text { Control: } 27 \\
( \pm 4.3)\end{array}$ & $\begin{array}{l}\text { Presence of } 4 \text { or more } \\
\text { teeth with probing } \\
\text { depth }>4 \mathrm{~mm} \text {. Patients } \\
\text { separated into two } \\
\text { categories: }<2.5 \mathrm{~mm} \\
\text { and }>2.5 \mathrm{~mm} \text { depth }\end{array}$ & $\begin{array}{l}\text { Treatment: } 200 \\
\text { Control: } 200\end{array}$ & $\begin{array}{l}\text { Preterm } \\
\text { birth; } \\
\text { preterm/low } \\
\text { birth weight }\end{array}$ \\
\hline Jeffcoat et al. 13 & 2003 & USA & Randomized & 366 & $\begin{array}{l}\text { Treatment: } 22.0 \\
\qquad( \pm 4.6) \\
\text { Control: } 22.2 \\
\quad( \pm 4.3)\end{array}$ & $\begin{array}{l}\text { Presence of } 4 \text { or more } \\
\text { teeth with } 1 \text { or more } \\
\text { sites with probing depth } \\
>4 \mathrm{~mm}\end{array}$ & $\begin{array}{l}\text { Treatment: } 246 \\
\text { Control: } 120\end{array}$ & $\begin{array}{l}\text { Preterm } \\
\text { birth }<37 \\
\text { weeks; } \\
\text { preterm/low } \\
\text { birth weight }\end{array}$ \\
\hline López et al. 14 & 2005 & Chile & Randomized & 870 & $\begin{array}{l}\text { Treatment: } 25.5 \\
\qquad( \pm 5.4) \\
\text { Control : } 29.9( \pm 4.5)\end{array}$ & $\begin{array}{l}\text { Gingival inflammation } \\
\text { with } \geq 25 \% \text { of sites with } \\
\text { bleeding upon probing } \\
\text { and no sites with clinical } \\
\text { attachment loss }>2 \mathrm{~mm}\end{array}$ & $\begin{array}{l}\text { Treatment: } 580 \\
\text { Control: } 290\end{array}$ & $\begin{array}{l}\text { Preterm } \\
\text { birth; } \\
\text { preterm/low } \\
\text { birth weight }\end{array}$ \\
\hline Michalowicz et al. 6 & 2006 & USA & Randomized & 812 & $\begin{array}{l}\text { Treatment: } 26.1 \\
\qquad( \pm 5.6) \\
\text { Control: } 25.9( \pm 5.5)\end{array}$ & $\begin{array}{l}\geq 4 \text { teeth with a probing } \\
\text { depth of } \geq 2 \mathrm{~mm} \text { and } \\
\text { bleeding upon probing } \\
\text { at } \geq 35 \% \text { of tooth sites }\end{array}$ & $\begin{array}{l}\text { Treatment: } 413 \\
\text { Control: } 410\end{array}$ & $\begin{array}{l}\text { Preterm } \\
\text { birth; } \\
\text { preterm/low } \\
\text { birth weight }\end{array}$ \\
\hline
\end{tabular}

(continues) 
Table 1 (continued)

\begin{tabular}{|c|c|c|c|c|c|c|c|c|}
\hline Reference & $\begin{array}{l}\text { Year of } \\
\text { publica- } \\
\text { tion }\end{array}$ & Country & Design & Patients & $\begin{array}{l}\text { Patient age in years } \\
\text { [mean (SD)] }\end{array}$ & $\begin{array}{l}\text { Diagnosis (periodontal } \\
\text { disease was defined as) }\end{array}$ & Participants & Outcomes \\
\hline Offenbacher et al. 16 & 2006 & USA & Randomized & 74 & $\begin{array}{l}\text { Treatment: } 26.8 \\
\begin{array}{c}( \pm 5.5) \text { Control: } 25.7 \\
( \pm 5.5)\end{array}\end{array}$ & $\begin{array}{l}\geq 2 \text { sites with probing } \\
\text { depth } \geq 5 \mathrm{~mm} \text { and peri- } \\
\text { odontal attachment loss } \\
\text { of } 1 \text { to } 2 \mathrm{~mm} \text { at one or } \\
\text { more depth } \geq 5 \mathrm{~mm}\end{array}$ & $\begin{array}{l}\text { Treatment: } 40 \\
\text { Control: } 34\end{array}$ & $\begin{array}{l}\text { Preterm } \\
\text { birth }\end{array}$ \\
\hline Sadatmansouri et al. 18 & 2006 & Iraq & Randomized & 30 & $\begin{array}{l}\text { Treatment: } 28.4 \\
\qquad( \pm 4.1) \\
\text { Control: } 29.1( \pm 4.3)\end{array}$ & $\begin{array}{l}\text { Having } \geq 4 \text { teeth with } \geq \\
\begin{aligned} 1 \text { site with pocket depth } \\
\\
\geq 4 \mathrm{~mm}\end{aligned}\end{array}$ & $\begin{array}{l}\text { Treatment: } 15 \\
\text { Control: } 15\end{array}$ & $\begin{array}{l}\text { Preterm } \\
\text { birth; } \\
\text { preterm/low } \\
\text { birth weight }\end{array}$ \\
\hline Tarannum \& Faizuddin 5 & 2007 & India & Randomized & 200 & $\begin{array}{l}\text { Treatment: } 23( \pm 3.3) \\
\text { Control: } 22( \pm 3.6)\end{array}$ & $\begin{array}{l}\text { Bleeding index treat- } \\
\text { ment group (\%): } 81.54 \\
(37-100) \\
\text { Bleeding index control } \\
\text { group (\%): } 83.63 \\
(40-100)\end{array}$ & $\begin{array}{l}\text { Treatment: } 100 \\
\text { Control: } 100\end{array}$ & $\begin{array}{c}\text { Preterm } \\
\text { birth; } \\
\text { preterm/low } \\
\text { birth weight }\end{array}$ \\
\hline Newnham et al. 15 & 2009 & Australia & Randomized & 1,087 & $\begin{array}{c}\text { Treatment: } 30.5 \\
( \pm 5.5) \text { Control: } 30.5 \\
( \pm 5.5)\end{array}$ & $\begin{array}{c}\text { The presence of peri- } \\
\text { odontal pockets } \geq 4 \mathrm{~mm} \\
\text { in depth at } \geq 12 \text { probing } \\
\text { sites in fully erupted } \\
\text { teeth }\end{array}$ & $\begin{array}{l}\text { Treatment: } 546 \\
\text { Control: } 541\end{array}$ & $\begin{array}{c}\text { Preterm } \\
\text { birth; low } \\
\text { birth weight }\end{array}$ \\
\hline Offenbacher et al. 17 & 2009 & USA & Randomized & 1,806 & $\begin{array}{l}\text { Treatment: } 25.4 \\
\qquad( \pm 5.5) \\
\text { Control: } 25.3( \pm 5.5)\end{array}$ & $\begin{array}{l}\geq 2 \text { sites of chronic in- } \\
\text { flammatory response to } \\
\text { tooth-associated micro- } \\
\text { bial biofilm (plaque) with } \\
>5 \mathrm{~mm} \text { probing depths }\end{array}$ & $\begin{array}{l}\text { Treatment: } 903 \\
\text { Control: } 903\end{array}$ & $\begin{array}{c}\text { Preterm } \\
\text { birth; } \\
\text { preterm/low } \\
\text { birth weight }\end{array}$ \\
\hline Macones et al. 3 & 2010 & USA & $\begin{array}{l}\text { Randomized, } \\
\text { multicenter }\end{array}$ & 756 & $\begin{array}{l}\text { Treatment: } 24.1 \\
\qquad( \pm 5.2) \\
\text { Control: } 24.2( \pm 5.7)\end{array}$ & $\begin{array}{c}\text { Attachment loss } \geq 3 \mathrm{~mm} \\
\text { in } \geq 3 \text { teeth }\end{array}$ & $\begin{array}{l}\text { Treatment: } 376 \\
\text { Control: } 380\end{array}$ & $\begin{array}{c}\text { Preterm } \\
\text { birth; low } \\
\text { birth weight }\end{array}$ \\
\hline Oliveira et al. 7 & 2010 & Brazil & Randomized & 246 & $\begin{array}{c}\text { Treatment: } 29.9 \\
\qquad( \pm 4.3) \\
\text { Control: } 26.5( \pm 3.98)\end{array}$ & $\begin{array}{l}\text { Presence of } \geq 4 \text { teeth } \\
\text { with } \geq 1 \text { site with prob- } \\
\text { ing depth }>4 \mathrm{~mm}\end{array}$ & $\begin{array}{l}\text { Treatment: } 122 \\
\text { Control: } 124\end{array}$ & $\begin{array}{l}\text { Preterm } \\
\text { birth; } \\
\text { preterm/low } \\
\text { birth weight }\end{array}$ \\
\hline Sant'Ana et al. 19 & 2011 & Brazil & Randomized & 31 & $\begin{array}{c}\text { Treatment: } 29.1 \\
\qquad( \pm 4.3) \\
\text { Control: } 26.5( \pm 3.9)\end{array}$ & $\begin{array}{l}\text { Presence of } 4 \text { or more } \\
\text { teeth with one or more } \\
\text { sites with pocket depth } \\
\quad \geq 4 \mathrm{~mm}\end{array}$ & $\begin{array}{l}\text { Treatment:16 } \\
\text { Control: } 15\end{array}$ & $\begin{array}{c}\text { Preterm } \\
\text { birth; } \\
\text { preterm/low } \\
\text { birth weight }\end{array}$ \\
\hline Weidlich et al. 20 & 2012 & Brazil & Randomized & 527 & $\begin{array}{l}\text { Treatment: } 28.8 \\
\qquad( \pm 4,7) \\
\text { Control:25.8 }( \pm 4.6)\end{array}$ & $\begin{array}{l}\text { Full-mouth, excluding } \\
\text { third molars, six sites } \\
\text { per tooth, periodontal } \\
\text { examination was carried } \\
\text { out. Unclear how } \\
\text { periodontal disease } \\
\text { was defined }\end{array}$ & $\begin{array}{l}\text { Treatment:145 } \\
\text { Control: } 154\end{array}$ & $\begin{array}{c}\text { Preterm } \\
\text { birth; } \\
\text { preterm/low } \\
\text { birth weight }\end{array}$ \\
\hline
\end{tabular}


Assessment of study quality.

\begin{tabular}{|c|c|c|c|c|c|c|c|c|c|}
\hline Reference & $\begin{array}{c}\text { Year of } \\
\text { publication }\end{array}$ & $\begin{array}{l}\text { Adequate } \\
\text { sequence } \\
\text { generation }\end{array}$ & $\begin{array}{c}\text { Allocation } \\
\text { concealment }\end{array}$ & Blinding & $\begin{array}{l}\text { Incomplete } \\
\text { outcome } \\
\text { data ad- } \\
\text { dressed }\end{array}$ & $\begin{array}{l}\text { Free of } \\
\text { selective } \\
\text { reporting }\end{array}$ & $\begin{array}{l}\text { Intention- } \\
\text { to-treat }\end{array}$ & $\begin{array}{c}\text { Free of } \\
\text { other bias }\end{array}$ & $\begin{array}{c}\text { Description of } \\
\text { other bias }\end{array}$ \\
\hline López et al. 12 & 2002 & Unclear & No & No & No & Yes & No & No & $\begin{array}{c}\text { Post-randomiza- } \\
\text { tion exclusion }\end{array}$ \\
\hline Jeffcoat et al. 13 & 2003 & Unclear & No & Unclear & No & Yes & Yes & No & $\begin{array}{l}\text { Baseline imbal- } \\
\text { ance }\end{array}$ \\
\hline López et al. 14 & 2005 & Unclear & No & No & No & Unclear & No & No & $\begin{array}{l}\text { Baseline imbal- } \\
\text { ance, post- } \\
\text { randomization } \\
\text { exclusion }\end{array}$ \\
\hline Michalowicz et al. 6 & 2006 & Yes & Yes & No & Yes & Yes & Yes & Yes & - \\
\hline Offenbacher et al. 16 & 2006 & Unclear & No & Unclear & Unclear & No & No & No & $\begin{array}{c}\text { Poorly described } \\
\text { statistical meth- } \\
\text { ods }\end{array}$ \\
\hline Sadatmansouri et al. 18 & 2006 & Unclear & No & No & Unclear & No & Yes & No & $\begin{array}{l}\text { Poorly described } \\
\text { statistical meth- } \\
\text { ods }\end{array}$ \\
\hline Tarannum \& Faizuddin 5 & 2007 & Unclear & No & No & No & No & No & No & $\begin{array}{c}\text { Poorly described } \\
\text { statistical meth- } \\
\text { ods }\end{array}$ \\
\hline Newnham et al. 15 & 2009 & Yes & Yes & No & Yes & Yes & Yes & Yes & - \\
\hline Offenbacher et al. 17 & 2009 & Yes & Yes & Unclear & No & Unclear & No & Yes & - \\
\hline Macones et al. 3 & 2010 & Unclear & No & No & No & Yes & No & No & $\begin{array}{l}\text { Post-randomiza- } \\
\text { tion exclusion }\end{array}$ \\
\hline Oliveira et al. 7 & 2010 & Unclear & No & No & No & Unclear & No & No & $\begin{array}{c}\text { Poorly described } \\
\text { statistical meth- } \\
\text { ods }\end{array}$ \\
\hline Sant'Ana et al. 19 & 2011 & Unclear & No & No & Yes & Unclear & No & No & $\begin{array}{c}\text { Poorly described } \\
\text { statistical meth- } \\
\text { ods }\end{array}$ \\
\hline Weidlich et al. 20 & 2012 & Unclear & No & No & No & Unclear & No & No & $\begin{array}{c}\text { Poorly described } \\
\text { methods }\end{array}$ \\
\hline
\end{tabular}

None of the authors discussed the effectiveness of periodontal treatment in the treatment group.

\section{Effects of interventions}

Preterm births < 37 weeks: a meta-analysis of 13 studies $3,5,6,7,12,13,14,15,16,17,18,19,20$ showed that periodontal disease treatment during pregnancy had no significant effect on the overall rate of preterm birth (RR $=0.90,95 \% \mathrm{CI}: 0.68-1.19 ; \mathrm{p}=0.45$; I2: 74\%) (Figure 2).

Low birth weight $<2,500 \mathrm{~g}$ : a meta-analysis of nine studies $3,5,6,7,12,14,15,17,20$ showed a weak association between periodontal disease treatment during pregnancy and decreases in low birth weight, with no significant effect $(\mathrm{RR}=0.92$, 95\%CI: 0.71-1.20; $\mathrm{p}=0.55$; $\mathrm{I}^{2}$ : 56\%) (Figure 3).

Heterogeneity was confirmed by the $\chi^{2}$ test, which produced a p-value of 0.00001 and 0.02 for preterm birth and low birth weight, respectively.

\section{Assessment of publication bias}

An examination of the funnel plot for our data suggests strong evidence of publication bias for the preterm birth and low birth weight outcomes in the meta-analysis. This bias was confirmed by the results of tests proposed by Steichen 24 , which produced $p$-values of 0.001 and 0.072 for preterm birth and low birth weight, respectively (Figure 4). 
Meta-analysis plot for preterm birth $<37$ weeks of gestation.

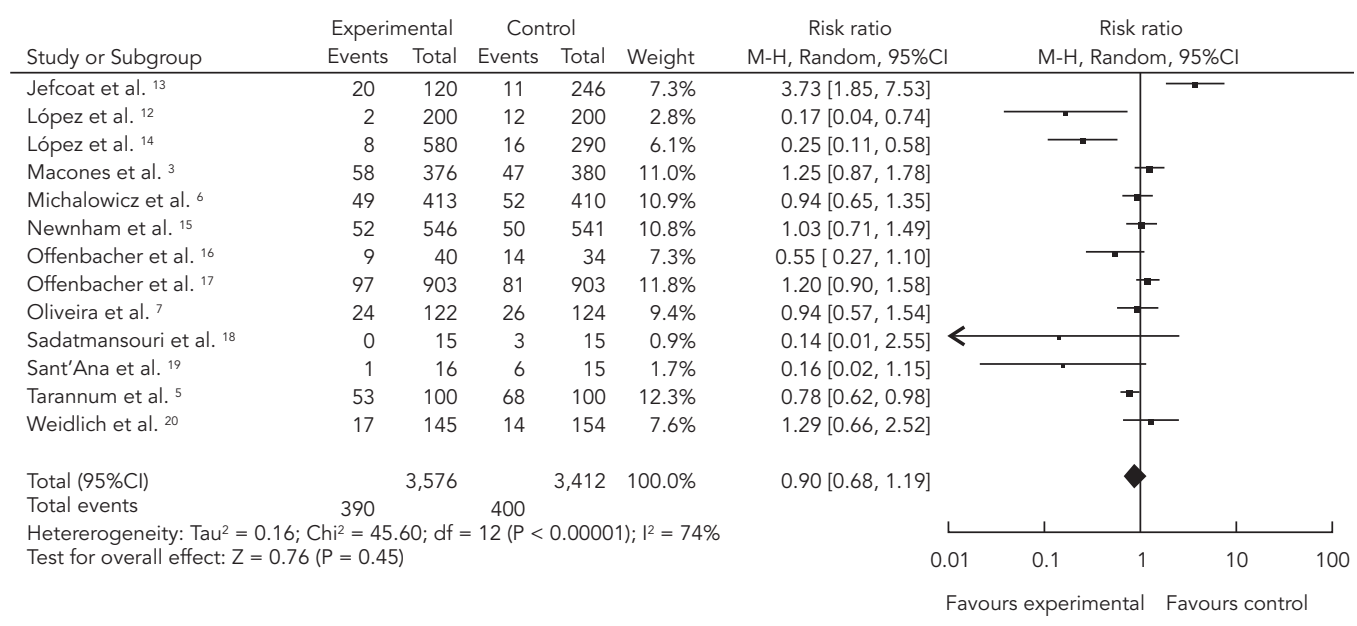

M-H: Mantel-Haenszel model; 95\% $\mathrm{Cl}$ : 95\% confidence interva

Figure 3

Meta-analysis plot for low birth weight $<2,500 \mathrm{~g}$.

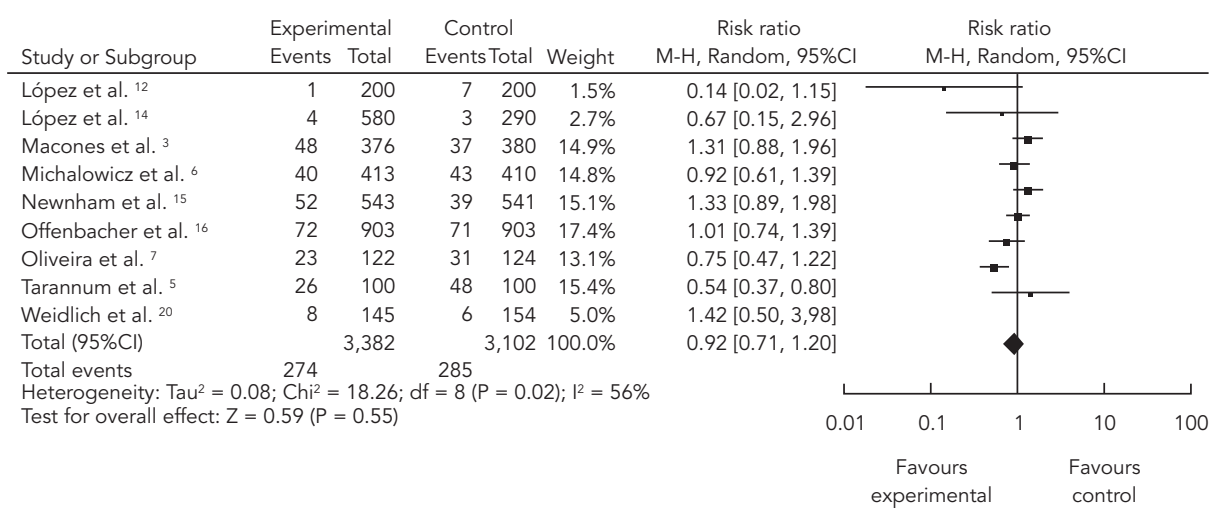

M-H: Mantel-Haenszel model; 95\% $\mathrm{Cl}$ : 95\% confidence interval

\section{Sensitivity analysis}

A sensitivity analysis was performed to test the robustness of the findings 24,25,26,27. Pooled treatment effect estimates from studies with adequate sequence generation, randomization and allocation concealment were analyzed 6,17,18.

\section{Discussion}

The World Health Organization (WHO) reported an estimated 12.9 million annual worldwide preterm births between 1997 and 2007, representing an incidence of $9.6 \% 28$. This meta-analysis showed that periodontal disease treatment during pregnancy does not confer a general protec- 


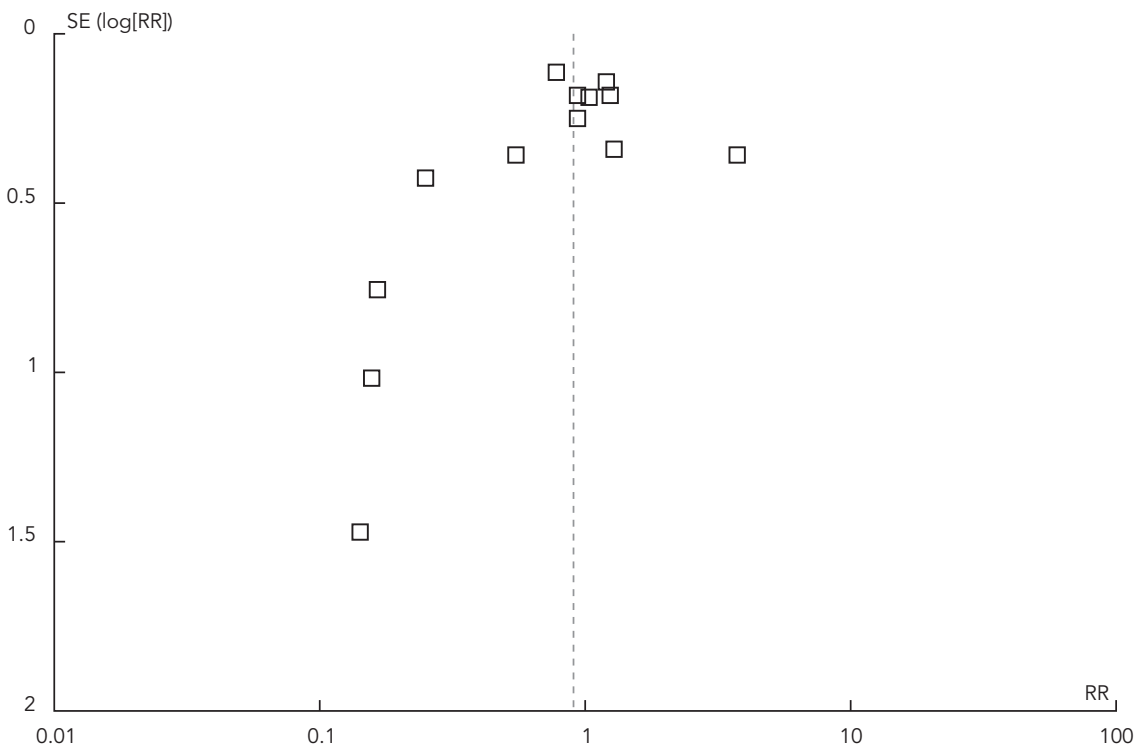

tion against preterm birth and low birth weight. Our systematic review identified 13 randomized $3,5,6,7,12,13,14,15,16,17,18,19,20$, relevant studies published between 200213 and 2012 20. These studies provided evidence from 6,988 pregnant women with periodontal disease who experienced a total of 790 preterm births. A second and equally important finding is that most of the studies included found no association between the subjects of study. In fact, the studies that rejected the alternative hypothesis were the most controlled and had the largest sample sizes.

\section{Strengths and limitations of this review}

Many aspects of this review lead us to believe that our results are valid. Firstly, we formulated a clinical question and then performed comprehensive searches that encompassed multiple online databases and searched the reference sections of relevant studies. No language restrictions were imposed and we used broad search terms to avoid making our question too specific to be adequately sensitive.

Although we did not seek any unpublished data, there is a risk of publication bias. However, we included only randomized, controlled trials to minimize selection bias. Many of the $\mathrm{I}^{2}$ esti- mates calculated in this meta-analysis may be considered high. This is a drawback, and may be the result of considerable heterogeneity between studies 9 .

\section{Comparisons with other studies}

Jeffcoat et al. 23 performed a randomized, controlled trial but included an intervention analysis based on the efficacy of periodontal treatment that differed from other studies. They found that successful, routine periodontal treatment was associated with decreased incidence of spontaneous preterm birth in the study population. We did not include this study in our systematic review because the intervention group included two subgroups (successful and unsuccessful) that were not found in other studies. According to Di Mario et al. 29 , the applied study design of Jeffcoat's 23 study does not permit the control of confounders and bias and, therefore, the lack of randomization and control for previous preterm birth affects the validity of this study.

Polyzos et al. 30 conducted a meta-analysis of randomized clinical trials to determine whether periodontal treatment during pregnancy reduced preterm birth. After examining eleven trials that included 6,558 patients, they found that 
periodontal treatment during pregnancy had no significant effect on the overall rate of preterm birth (OR = 1.15, 95\%CI: 0.95-1.40; $\mathrm{p}=0.15)$. In 2011, two meta-analyses were published by Chambrone et al. 31 and Fogacci et al. 32, including 11 and 10 trials, respectively, neither of which supported the hypothesis that periodontal therapy reduces preterm birth and low birth weight indices.

In contrast, a meta-analysis published in 2011, including ten eligible trials with 5,645 pregnant women, found that periodontal treatment significantly lowered preterm birth $(\mathrm{OR}=0.65$; 95\%CI: 0.45-0.93; $\mathrm{p}=0.02)^{33}$.

The differences reported can be explained by the different strategies employed in the meta-analysis. George et al. ${ }^{33}$ pooled all the trials together, while Polizos et al. 30 conducted the review by analyzing the high and low-quality trials.

\section{Resumo}

Os eventos que levam à prematuridade ainda não são completamente compreendidos. Foi realizada uma revisão sistemática quantitativa para avaliar os efeitos do tratamento de doença periodontal durante a gravidez para prevenir o nascimento prematuro e baixo peso ao nascer. A metanálise incluiu estudos randomizados de grávidas com diagnóstico de doença periodontal antes de 20 semanas de gestação. $O$ risco relativo $(R R)$ com intervalos de 95\% de confiança (IC95\%) foi calculado. Avaliou-se os desfechos prematuridade e baixo peso ao nascer. Foram incluídos 13 estudos, comparando 3.576 mulheres em grupos de intervenção com 3.412 mulheres que receberam tratamento habitual. A metanálise mostrou uma redução não significativa nos partos prematuros ( $R R=0,90$; IC95\%: 0,68-1,19) e baixo peso ao nascer $(R R=0,92$; IC95\%: 0,71-1,20). O gráfico de funil revelou clara evidência de viés de publicação. Em resumo, o tratamento periodontal em mulheres grávidas não pode ser considerado uma forma eficiente de reduzir a incidência de parto prematuro ou baixo peso ao nascer.

Doenças Periodontais; Nascimento Prematuro; RecémNascido de Baixo Peso; Revisão; Metanálise
Our study included 6,988 patients, all items covered by Polyzos et al. 30 and two other clinical trials published in subsequent years 20,29. Our results corroborate Polyzos's and Chambrone's findings 30,31. Two other systematic reviews were published in 2006 and 2007, but used case-control, cohort and controlled trials 34,35 .

\section{Conclusions}

Primary periodontal care during pregnancy cannot reduce the rate of preterm birth or low birth weight. Although this review found no benefits of periodontal care during pregnancy, future research is needed to address this important question.

\section{Contributors}

M. I. Rosa contributed to the study conception, literature search, data extraction and analysis, statistical analysis, preparation and revision of the manuscript and definition of intellectual content. P. D. S. Pires contributed to the literature search, data extraction and interpretation and editing of the manuscript. L. R. Medeiros contributed to the study conception, data analysis, statistical analysis, preparation and revision of the manuscript and definition of intellectual content. M. I. Edelweiss contributed to the study conception, preparation of the manuscript and definition of intellectual content. J. Martínez-Mesa contributed to data interpretation. All authors approved the final version of the manuscript. 


\section{References}

1. Roman AS, Pernoll ML. Late pregnancy complications. In: DeCherney AH, Nathan L, editors. Current obstetrics \& gynecologic diagnosis \& treatment. Los Angeles: McGraw-Hill; 2003. p. 286-300.

2. Beck S, Wojdyla D, Say L, Betran AP, Merialdi M, Requejo $\mathrm{JH}$, et al. The worldwide incidence of preterm birth: a systematic review of maternal mortality and morbidity. Bull World Health Organ 2010; 88:31-8

3. Macones GA, Parry S, Nelson DB, Strauss JF, Ludmir J, Cohen AW, et al. Treatment of localised periodontal disease in pregnancy does not reduce the occurrence of preterm birth: results from the Periodontal Infections and Prematurity Study (PIPS). Am J Obstet Gynecol 2010; 202:147-8.

4. Cobo T, Palacio M, Martínez-Terrón M, NavarroSastre A, Bosch J, Filella X, et al. Clinical and inflammatory markers in amniotic fluid as predictors of adverse outcomes in preterm premature rupture of membranes. Am J Obstet Gynecol 2011; 205:126.e1-8.

5. Tarannum F, Faizuddin M. Effect of periodontal therapy on pregnancy outcome in women affected by periodontitis. J Periodontol 2007; 78:2095-103.

6. Michalowicz BS, Hodges JS, DiAngelis AJ, Lupo VR, Novak MJ, Ferguson JE, et al. Treatment of periodontal disease and the risk of preterm birth. N Engl J Med 2006; 355:1885-94.

7. Oliveira AM, de Oliveira PA, Cota LO, Magalhães CS, Moreira AN, Costa FO. Periodontal therapy and risk for adverse pregnancy outcomes. Clin Oral Invetig 2010; [Epud ahead of print].

8. Liberatti A, Altman DG, Tetzlaff J, Mulrow C, Gøtzsche PC, Ioannidis JP, et al. The PRISMA statement for reporting systematic review and meta-analysis of studies that evaluate healthcare interventions: explanation and elaboration. BMJ 2009; 339:b2700.

9. DerSimonian R, Laird N. Meta-analysis in clinical trials. Control Clin Trials 1986; 7:177-88.

10. Deeks JJ, Higgins JPT, Altman DG. Analyzing data and undertaking meta-analysis. In: Higgins J, Green S, editors. Cochrane handbook for systematic reviews of interventions 5.0.1. Oxford: The Cochrane Collaboration; 2008. p. 239-43.

11. Higgins J, Altmann DG. Assessing risks of bias in included studies. In: Higgins J, Green S, editors. Cochrane handbook for systematic reviews of interventions 5.0.1. Oxford: The Cochrane Collaboration; 2008. p. 188-235.

12. López NJ, Smith PC, Gutierrez J. Periodontal therapy may reduce the risks of preterm low birth weight in women with periodontal disease: a randomized controlled trial. J Periodontol 2002; 73:911-24.

13. Jeffcoat MK, Hauth JC, Geurs NC, Reddy MS, Cliver SP, Hodgkins PM, et al. Periodontal disease and preterm birth: results of a pilot intervention study. J Periodontol 2003; 74:1214-8.

14. López NJ, Da Silva I, Ipinza J, Gutiérrez J. Periodontal therapy reduces the race of preterm low birth weight in women with pregnancy-associated gingivitis. J Periodontol 2005; 76:2144-53.
15. Newnham JP, Newnham IA, Ball CM, Wright M, Pennell CE, Swain J, et al. Treatment of periodontal disease during pregnancy: a randomised controlled trial. Obstet Gynecol 2009; 114:1239-48.

16. Offenbacher S, Lin D, Strauss R, McKaig R, Irving J, Barros SP, et al. Effects of periodontal therapy during pregnancy on periodontal status, biologic parameters, and pregnancy outcomes: a pilot study. J Periodontol 2006; 77:2011-24.

17. Offenbacher S, Beck JD, Jared HL, Mauriello SM, Mendoza LC, Couper DJ, et al. Effects of periodontal therapy on the rate of preterm delivery: a randomised controlled trial. Obstet Gynecol 2009; 114:551-9.

18. Sadatmansouri S, Sedighpoor N, Aghaloo M. Effects of periodontal treatment phase I on birth term and birth weight. J Indian Soc Pedod Prev Dent 2006; 24:23-6.

19. Sant'Ana AC, Campos MR, Passanezi SC, Rezende ML, Greghi SL, Passanezi E. Periodontal treatment during pregnancy decreases the rate of adverse pregnancy outcome: a controlled clinical trial. J Appl Oral Sci 2011; 19:130-6.

20. Weidlich P, Moreira CH, Fiorini T, Musskopf ML, Rocha JM, Oppermann ML, et al. Effect of nonsurgical periodontal therapy and strict plaque control on preterm/low birth weight: a randomized controlled clinical trial. Clin Oral Investig 2012; [Epub ahead of print]

21. Radnai M, Pál A, Novák T, Urbán E, Eller J, Gorzó I. Benefits of periodontal therapy when preterm birth threatens. J Dent Res 2009; 88:280-4.

22. Novak JM, Novak KF, Hodges JS, Kirakodu S, Govindaswami M, Diangelis A, et al. Periodontal bacterial profiles in pregnant women: response to treatment and associations with birth outcomes in the Obstetrics and Periodontal therapy (OPT) study. J Periodontol 2008; 79:1870-9.

23. Jeffcoat M, Parry S, Sammel M, Clothier B, Catlin A, Macones G. Periodontal infection and preterm birth: successful periodontal therapy reduces the risk of preterm birth. BJOG 2011; 118:250-6.

24. Steichen TJ. Tests for publication bias in metaanalysis. In: Sterne J, Newton HJ, Cox NJ, editors. Meta-analysis in Stata: an updated collection from the Stata Journal. College Station: Stata Press; 2009. p. 151-64.

25. Jüni P, Altman, Egger M. Assessing the quality of randomized controlled trials. In: Egger M, Smith GD, Altman DG, editors. Systematic reviews in health care: meta-analysis in context. 2nd Ed. London: BMJ Publishing; 2001. p. 248-82.

26. Sutton AJ, Abrams KR, Jones DR, Sheldon TA, Song F. Random effects methods for combining study estimates. In: Sutton AJ, Abrams KR, Jones DR, Sheldon TA, Song F, editors. Methods for metaanalysis in medical research. Chichester: John Wiley; 2000. p. 73-86.

27. Sterne JA, Egger M, Smith GD. Investigating and dealing with publication and other biases in metaanalysis. BMJ 2001; 323:101-5. 
28. World Health Organization. Perinatal health. http://www.who.int/reproductivehealth/topics/ maternal_perinatal/perinatal.pdf (accessed on Oct/2011).

29. Di Mario S, Spettoli D, Alessandrini C, Erenbourg A, Ronfani L, Basevi V. Periodontal infection and preterm birth: successful periodontal therapy reduces the risk of preterm birth. BJOG 2011; 118:635.

30. Polyzos NP, Polyzos IP, Zavos A, Valachis A, Mauri D, Papanikolaou EG, et al. Obstetric outcomes after treatment of periodontal disease during pregnancy: systematic review and meta-analysis. BMJ 2010; 341:c7017.

31. Chambrone L, Pannuti CM, Guglielmetti MR, Chambrone LA. Evidence grade associating periodontitis with preterm birth and/or low birth weight: II: a systematic review of randomized trials evaluating the effects of periodontal treatment. J Clin Periodontol 2011; 38:902-14.
32. Fogacci MF, Vettore MV, Leão AT. The effect of periodontal therapy on preterm low birth weight: a meta-analysis. Obstet Gynecol 2011; 117:153-65.

33. George A, Shamim S, Johnson M, Ajwani S, Bhole S, Blinkhorn A, et al. Periodontal treatment during pregnancy and birth outcomes: a meta-analysis of randomised trials. Int J Evid Based Healthc 2011; 9:122-47.

34. Xiong X, Buekens P, Fraser WD, Beck J, Offenbacher S. Periodontal disease and adverse pregnancy outcomes: a systematic review. BJOG 2006; 113: 135-43.

35. Vergnes JN, Sixou M. Preterm low birth weight and maternal periodontal status: a meta-analysis. Am J Obstet Gynecol 2007; 196:135.e1-135.e7.

Submitted on 25/Mar/2012

Final version resubmitted on 19/Jun/2012

Approved on 03/Jul/2012 